\title{
PENERAPAN METODE ASOSIASI MENGGUNAKAN ALGORITMA APRIORI PADA APLIKASI ANALISA POLA BELANJA KONSUMEN (Studi Kasus Toko Buku Gramedia Bintaro)
}

\author{
Dewi Listriani ${ }^{1}$, Anif Hanifa Setyaningrum ${ }^{2}$, Fenty Eka M. A. ${ }^{3}$ \\ 1,2,3 Prodi Teknik Informatika, Universitas Islam Negeri Jakarta \\ ${ }^{1}$ dewi.listriani@gmail.com, ${ }^{3}$ fenty.eka@ uinjkt.ac.id
}

\begin{abstract}
ABSTRAK
Toko Buku Gramedia merupakan salah satu perusahaan besar yang bergerak dibidang ritel yang mana perusahaan ini setiap harinya harus memenuhi kebutuhan konsumen dan dituntut untuk mengambil keputusan yang tepat dalam menentukan strategi penjualan. Dengan memanfaatkan data transaksi penjualan yang telah tersimpan dalam database, pihak manajemen dapat mengetahui kebiasaan pelanggan atau perilaku pelanggan mengenai apa saja buku yang sering dibeli. Cara mengetahui buku-buku yang dibeli secara bersamaan, dapat digunakan association rule (aturan asosiasi), yaitu teknik data mining untuk menemukan aturan asosiasi suatu kombinasi item. Proses pencarian asosiasi menggunakan bantuan algoritma apriori untuk menghasilkan pola kombinasi item dan rules sebagai ilmu pengetahuan dan informasi penting dari data transaksi penjualan. Hasil penelitian ini berupa aplikasi untuk menganalisa pola belanja yang mana pola yang dihasilkan dapat dijadikan rekomendasi dalam menentukan strategi penjualan oleh pihak Gramedia.
\end{abstract}

Kata kunci : analisa pola belanja, metode asosiasi, apriori, nilai support.

\begin{abstract}
Gramedia Bookstore is one of the major companies engaged in retail where this company every day to meet the needs of consumers and be required to take the right decision in determining sales strategy. By leveraging the sales transaction data that has been stored in the database, the management can know the habits of the customer or customer behavior regarding what books are often purchased. How to know the books are purchased simultaneously, can be used association rule (association rules), ie data mining techniques to discover the rules of association of a combination of items. The search process using aid association priori algorithm to generate the pattern of combinations of items and rules as science and critical information from the sales transaction data. The results of this study in the form of an application to analyze spending patterns where the patterns produced can be used in determining sales strategy recommendations by the Gramedia.
\end{abstract}

Keywords : analysis of spending patterns, methods of association, apriori, the value of support 


\section{PENDAHULUAN}

Perkembangan dan persaingan bisnis dalam perdagangan dunia melalui ekonomi pasar bebas dan kemajuan teknologi informasi membawa perusahaan pada tingkat persaingan yang semakin ketat dan semakin terbuka dalam memenuhi tuntutan pelanggan yang juga semakin tinggi. Bisnis dalam abad informasi ini juga harus bersaing dalam pasar dengan perubahan cepat, kompleks, global, sangat kompetitif dan terfokus pada pelanggan. Bahkan menurut Knoke (1995) faktor - faktor tersebut kadang-kadang berubah secara tidak terduga (Suyanto, 2005). Sehingga para pengembang dan pelaku bisnis harus mencari solusi dan memikirkan strategistrategi terobosan yang dapat menjamin keberlangsungan bisnis mereka.

Pada bisnis ritel, salah satu cara yang bisa dilakukan untuk mengetahui kondisi pasar (pelanggan) adalah dengan mengamati data transaksi penjualan. Data transaksi penjualan disimpan dalam basis data server dan kemudian data inilah yang diolah sehingga dihasilkan laporan penjualan dan laporan laba rugi. Akan tetapi, data penjualan tersebut dapat diolah lebih lanjut sehingga didapatkan informasi baru (Erwin, 2009).

Toko Buku Gramedia merupakan salah satu perusahaan besar yang bergerak dibidang ritel dengan produk utama buku dan alat-alat tulis. Perusahaan ini setiap harinya harus memenuhi kebutuhan konsumen dan dituntut untuk mengambil keputusan yang tepat dalam menentukan strategi penjualan. Untuk dapat melakukan hal tersebut, perusahaan membutuhkan sumber informasi yang cukup banyak untuk dapat dianalisis lebih lanjut. Misalnya dengan memanfaatkan data transaksi penjualan yang telah tersimpan dalam database, pihak manajemen dapat mengetahui kebiasaan pelanggan atau perilaku pelanggan mengenai apa saja buku yang sering dibeli. Untuk menganalisis kebiasaan pelanggan tersebut dapat digunakan analisis keranjang pasar (market basket analysis) yaitu suatu metode yang dapat digunakan untuk menganalisis perilaku pola belanja konsumen. Analisis ini bertujuan menemukan produk- produk yang sering dibeli bersamaan dari data transaksi.

Cara mengetahui buku-buku yang dibeli secara bersamaan, dapat digunakan association rule (aturan asosiasi), yaitu teknik data mining untuk menemukan aturan asosiatif suatu kombinasi item. Pencarian pola asosiasi berawal dari pengolahan data transaksi penjualan buku, kemudian dicari hubungan antar buku yang dibeli. Proses pencarian asosiasi ini menggunakan bantuan algoritma apriori yang merupakan algoritma yang digunakan untuk menghasilkan association rule dengan pola "if then" yang berfungsi untuk membentuk kombinasi item yang mungkin, kemudian diuji apakah kombinasi tersebut memenuhi parameter support dan confidence minimum yang merupakan nilai ambang yang diberikan oleh user. Dengan algoritma apriori tersebut akan menghasilkan pola kombinasi item dan rules sebagai ilmu pengetahuan dan informasi penting dari data transaksi penjualan (Buulolo, 2013). Pola kombinasi yang item yang dihasilkan sangat bermanfaat untuk penjualan silang ( $\neg$ crossselling), desain katalog, add-on selling, tata letak toko dan untuk mengetahui segmentasi pelanggan (Agrawal \& Srikant, 1994).

\section{LANDASAN TEORI}

\section{A. Data Mining}

Data mining adalah proses yang memperkerjakan satu atau lebih teknik pembelajaran komputer (machine learning) untuk menganalisis dan mengekstrasi pengetahuan (knowledge) secara otomatis. Data mining merupakan proses iterative dan interaktif untuk menemukan pola atau model baru yang sahih (sempurna), bermanfaat dan dapat dimengerti dalam suatu database yang besar (Hermawati, 2013).Hal penting yang terkait dengan data mining (Kusrini, 2009) adalah :

1. Data mining merupakan suatu proses otomatis terhadap data yang sudah ada.

2. Data yang akan diproses berupa data yang sangat besar.

3. Tujuan data mining adalah untuk mendapatkan hubungan atau pola yang mungkin memberikan indikasi yang bermanfaat.

\section{B. Tahapan Data Mining}


Menurut CRISP-DM sebuah proyek data mining memiliki siklus hidup yang terbagi dalam enam fase seperti gambar dibawah ini :

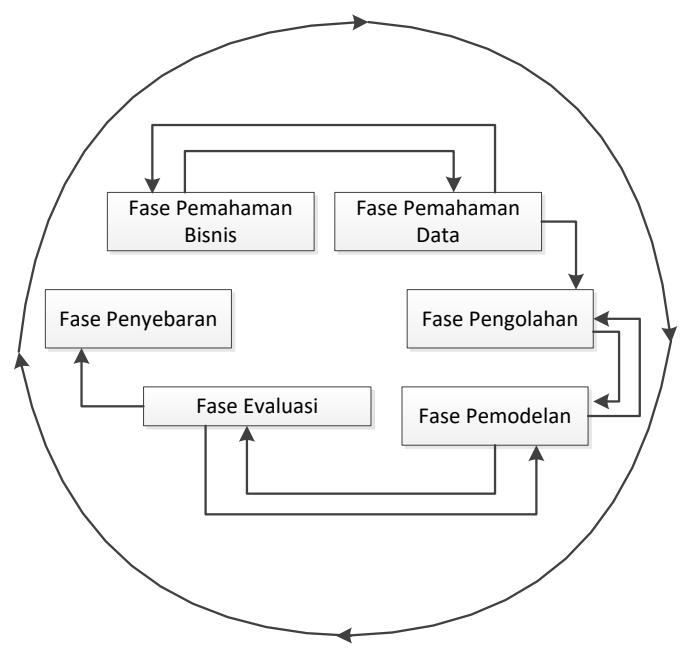

\section{Gambar 1. Proses Data Mining Menurut CRISP-DM (Kusrini, 2009)}

Menurut Larose (2005) enam fase data mining menurut CRISP-DM yaitu :

1. Fase pemahaman bisnis (Bussiness Understanding Phase)

2. Fase Pemahaman Data (Data Understanding Phase)

3. Fase Pengolahan Data (Data Preparation Phase)

4. Fase pemodelan (Modelling Phase)

5. Fase Evaluasi (Evaluation Phase)

6. Fase Penyebaran (Deployment Phase) (Sumber : Kusrini, 2009)

\section{Aturan Asosiasi}

Ketersediaan database mengenai catatan transaksi pembelian para pelanggan suatu supermarket atau tempat lain, telah mendorong pengembangan teknik-teknik yang secara otomatis menemukan asosiasi produk atau item-item yang tersimpan dalam database tersebut.sebagai contoh adalah data mengenai transaksi pada supermarket. Data transaksi mendaftar semua item yang dibeli oleh pelanggan dalam suatu transaksi pembelian tunggal. Para manajer ingin tahu apakah suatu kelompok item selalu dibeli secara bersama-ama. Para manajer tersebut bisa menggunakan informasi tersebut untuk membuat layout supermarket, sehingga penyusunan item-item tersebut bisa optimal satu sama lain atau untuk keperluan promosi, segmentasi pembeli, pembuatan katalog produk, atau melihat pola belanja. Aturan asosiasi ingin memberikan informasi tersebut dalam bentuk hubungan "if-then" atau "jika-maka" yang dihitung dari data yang sifatnya probabilistik.

Ide dari aturan asosiasi adalah untuk memeriksa semua kemungkinan hubungan if-then antar item dan memilih hanya yang paling mungkin (most likely) sebagai indikator dari hubungan ketergantungan antar item. Biasanya digunakan istilah antedecent untuk mewakili bagian "jika" dan consequent untuk mewakili bagian "maka". Dalam analisis ini. Antedecent dan consequent adalah sekelompok item yang tidak punya hubungan secara bersama (Santosa, 2007).

Metodologi dasar aturan asosiasi terbagi menjadi dua tahap (Kusrini, 2009) yaitu :

1. Analisis pola frekuensi tinggi

Tahap ini mencari kombinasi item yang memenuhi syarat minimum dari nilai support dalam database. Nilai support (penunjang) yaitu persentase item atau kombinasi item yang ada pada database. Nilai support sebuah item diperoleh dengan rumus berikut :

Support $(A)=\frac{\text { Jumlah Transaksi mengandung } A}{\text { Jumlah Transaksi }}$

Sedangkan nilai dari support 2 item diperoleh dari rumus berikut :

2. Pembentukan aturan asosiatif

Setelah semua pola frekuensi tinggi ditemukan, maka dicari aturan asosiatif yang memenuhi syarat minimum untuk confidence dengan menghitung confidence aturan asosiatif "Jika A maka B" $=(\mathrm{A} \rightarrow \mathrm{B})$.

$$
\text { Confidence }=P(B \mid A)=\frac{\sum \text { Transaksi mengandung } A \text { dan } B}{\Sigma \text { Transaksi mengandung } A}
$$

\section{Algoritma Apriori}

Algoritma apriori adalah satu algoritma dasar yang diusulkan oleh Agrawal dan Srikan pada tahun 1994 untuk menemukan frequent itemsets pada aturan asosiasi Boolean. Ide utama pada algoritma apriori adalah : pertama, mencari frequent itemset (himpunan item-item yang memenuhi minimum support.) dari basis data transaksi, kedua - menghilangkan itemset degaan frekuensi yang rendah berdasarkan level minimum support yang telah ditentukan sebelumnya. Selanjutnya membangun aturan asosiasi dari itemset yang memenuhi nilai minimum confidence dalam basis data (Agrawal \& Srikant, 1994).

Untuk membentuk kandidat itemset ada dua proses utama yang dilakukan algoritma apriori (Han \& kamber, 2006) :

1. Join Step (Penggabungan)

Pada proses ini setiap item dikombinasikan dengan item lainnya sampai tidak terbentuk kombinasi lagi.

2. Prune Step (Pemangkasan)

Pada proses ini, hasil dari item yang dikombinasikan tadi kemudian dipangkas dengan 
menggunakan minimum support yang telah ditentukan oleh user

Berikut adalah pseudocode dari algoritma apriori (Adewole, dkk (2014)):

\section{Procedure Apriori_Algorithm()}

Input: $D$, a database of transactions; min_sup, the minimum support count threshold

Output: $L$, frequent itemsets in $D L 1=\{$ frequent items\};

Steps:

(1) $L 1$ = find_frequent_1-itemsets(D);

(2) for $(k=2 ; L k-1 \neq \phi ; k++)\{$

(3) $\quad C k=$ apriori_gen $(L k-1)$;

(4) for each transaction $\{/ /$ scan $D$ for counts

(5) $\quad C t=\operatorname{subset}(C k, t i$;

(6) for each candidate $c \in \mathrm{Ct}$

(7)

(8) $\quad$ endfor

(9) $\quad L k=\{c \in C k \mid$ c.count min_sup $\}$

(10) endfor

(11) return $L=\cup k L k$;

\section{Procedure apriori_gen $(L k-1$ : frequent $(k-1)$ -} itemsets)

(1) for each itemset $l 1 \in L k$-1

(2) for each itemset $l 2 \in L k-1$

(3) if $(l 1[1]=l 2[1]) \wedge(l 1[2]=l 2[2]) \wedge::: \wedge(l 1[k-$ $2]=l 2[k-2]) \wedge(l 1[k-1]<l 2[k-1])$ then \{

(4) $\quad c=l 1 \times l 2$;

(5) if has_infrequent_subset $(c, L k-1)$ then

(6) $\quad$ delete $c$;

(7) else add $c$ to $C k$;

(8) endif

(9) return $C k$;

Procedure has_infrequent_subset $(c$ : candidate $k$ itemset; $L k$-1: frequent $(k-1)$-itemsets $)$; //use prior knowledge

(1) for each $(k-1)$-subset $s$ of $c$

\section{E. Analisa Keranjang Belanja}

Menurut David Olson dan Yong Shi (2008), analisis keranjang belanja mengacu pada berbagai teknologi yang mempelajari komposisis keranjang belanja yang terdiri atas produk-produk yang dibeli pada satu kejadian belanja. Teknik ini telah diterapkan secara luas dalam berbagai operasi pasar swalayan. Data keranjang belanja dalam bentuknya yang paling mentah adalah daftar transaksi pembelian oleh pelanggan, yang mengindikasikan hanya barang yang dibeli bersamaaan.

\section{METODOLOGI PENELITIAN}

Tahapan penelitian ini penulis gambarkan dalam sebuah kerangka berfikir penelitian sebagai berikut :

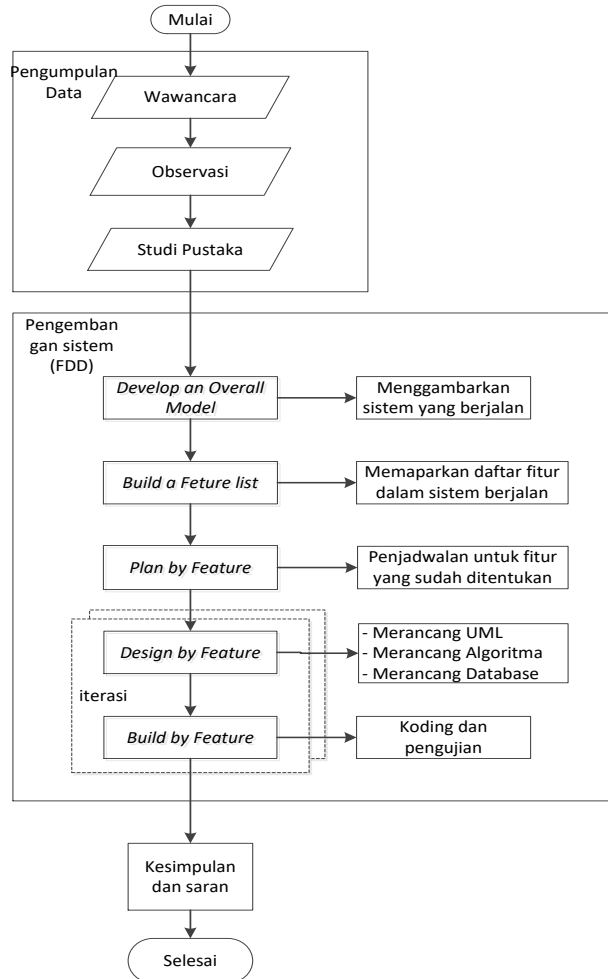

Gambar 2. Kerangka Penelitian

\section{HASIL DAN PEMBAHASAN}

\subsection{Develop an Overall Model}

Pada tahap Develop an Overall Model penulis akan memaparkan tentang gambaran sistem yang berjalan di Gramedia, identifikasi masalah dan rumusan masalah yang merupakan fase pemahaman bisnis dan pemahaman data pada tahapan data mining. Adapun permasalahan yang penulis identifikasi khususnya dalam pengolahan data adalah belum adanya informasi tambahan dari data transaksi penjualan yang ada. Hal ini terlihat dari informasi yang dihasilkan pada fitur sell di aplikasi RDW yang dipakai oleh Gramedia. Padahal dengan data transaksi penjualan tersebut dengan penerapan metode asosiasi dapat membantu pemilik usaha untuk menemukan keterkaitan atau pola kemunculan barang dalam transaksi penjualan, yang pada akhirnya dapat digunakan untuk menyusun strategi penjualan (Emha, 2009).

\subsection{Build a Feature List}

Pada tahap ini, penulis membuat daftar fitur apasaja yang akan di tambahkan pada fitur sales audit di sistem yang sudah berjalan di Gramedia. Antara lain :

Tabel 1. Daftar Fitur

Feature set : Mengelola Transaksi

Penjualan

1. Menampilkan daftar transaksi $\quad$ Sistem 


\begin{tabular}{|r|l|l|}
\hline 2. & Menambahkan data transaksi & Admin \\
\hline 3. & Melakukan analisis pola & Sistem \\
\hline 4. & $\begin{array}{l}\text { Melakukan pencarian } \\
\text { rekomendasi }\end{array}$ & Sistem \\
\hline
\end{tabular}

\subsection{Perencanaan Setiap Fitur (Plan by Feature)}

Pada tahap plan by feature akan dilakukan penjadwal an pembuatan fitur yang telah didaftar pada tahap build a feature list.

\subsection{Desain Fitur (Design by Feature)}

Pada tahap design by feature akan dilakukan perancangan terhadap fitur yang telah ditentukan yang mana pada tahap ini penulis membuat perancangan algoritma Apriori untuk algoritma yang akan dipakai pada analisa pola belanja, perancangan UML dan perancangan database.

\subsubsection{Perancangan Algoritma}

\section{Proses Asosiasi Algoritma Apriori}

Secara umum dalam pembentukan pola asosiasi oleh algoritma apriori ada dua tahapan yaitu pertama, mencari frequent itemset (himpunan item yang memenuhi nilai minimum support). Kedua, membentuk pola asosiasi dari frequent itemset yang telah didapat dengan menggunakan nilai confidence.Berikut adalah bagian dari atribut algoritma apriori:

a. Nilai Support (nilai penunjang): persentase kombinasi item dalam database.

b. Nilai confidence (nilai kepastian): kuatnya hubungan antar-item dalam aturan asosiasi.

c. Itemset : himpunan item-item yang ada dalam transaksi.

d. $\quad k$-itemset : itemset yang berisi $k$ item. Misalnya : $\{$ The, Gula $\}$ adalah sebuah 2-itemset.

e. candidate $k$-itemset $(C k)$ : calon $k$ itemset dari data transaksi.

f. Frequent $k$-itemset $(L k)$ : itemset yang memiliki frekuensi kemunculan lebih dari nilai minimum yang telah ditentukan.

\section{Cara Kerja Algoritma Apriori}

Dari data transaksi penjualan Toko Buku Gramedia diambil sebanyak 12 data transaksi sebagai sample untuk penerapan algoritma apriori dalam pembentukan pola asosiasi untuk menganalisa pola belanja konsumen di toko buku tersebut. Percobaan dilakukan dengan menggunakan parameter-parameter berikut :

Jumlah Data : 12

Jumlah Atribut : 5 (Agriculture, Business, Children's Book, Diet\&Helath dan Entertainment)

Nilai minimum support : 2

Nilai minimum confidence : $75 \%$

Berikut adalah data transaksi yang akan dianalisa :

Tabel 2 Data Transaksi

\begin{tabular}{|r|l|r|l|}
\hline NOTRANS & ITEM_ID & QTY & \multicolumn{1}{|c|}{ NAMA_KATEGORI } \\
\hline 1 & 200731154 & 1 & AGRICULTURE \\
\hline 1 & 200034109 & 1 & CHILDREN'S BOOKS \\
\hline 1 & 203671333 & 1 & DIET \& HEALTH \\
\hline 2 & 203900833 & 1 & BUSINESS \\
\hline 2 & 204087933 & 1 & CHILDREN'S BOOKS \\
\hline 2 & 203177199 & 1 & ENTERTAINMENT \\
\hline 3 & 203538801 & 1 & AGRICULTURE \\
\hline 3 & 203782134 & 1 & BUSINESS \\
\hline 3 & 204049950 & 1 & CHILDREN'S BOOKS \\
\hline
\end{tabular}

\section{Pencarian Frequent Itemset}

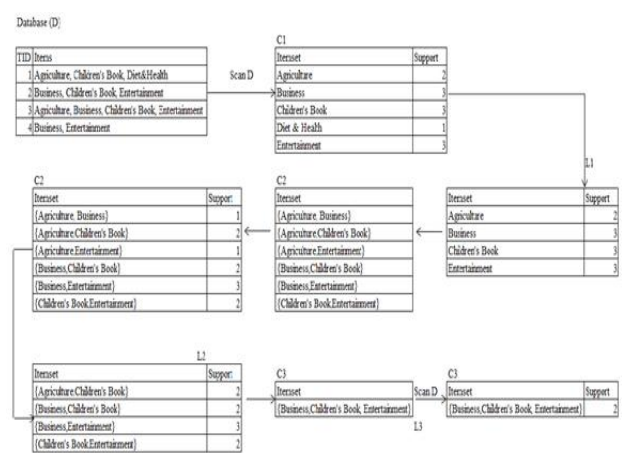

Pembentukan aturan asosiasi

Untuk pembentukan aturan asosiasi, frequent itemset yang telah didapat akan dibentuk menjadi pola "jika A, maka B (A $\rightarrow$ B)" dan akan dicari nilai confidence masing- masing pola tersebut dengan rumus :

$$
\text { Confidence }=P(B \mid A)=\frac{\Sigma \text { Transaksi mengandung } A \text { dan } B}{\Sigma \text { Transaksi mengandung } A}
$$

Sebagai contoh, perhitungan nilai confidence aturan asosiasi \{Business, Children's Book\} $\rightarrow$ \{Entertainment $\}$ adalah :

Conf $(\{$ Business, Children's Book $\} \quad \rightarrow$ \{Entertainment $\})$

$$
=
$$

Support [Business, Children's Book Entertainment] Support [Business, Children's Book] $100 \%$

$$
\begin{aligned}
& =\frac{2}{2} \times 100 \% \\
& =100 \%
\end{aligned}
$$

Conf $(\{$ Business, Entertainment $\} \rightarrow\{$ Children's Book $\}$ ) 
Support [Business children's Book Entertainment]] $\times$ $100 \%$

$$
\text { Support [Business, Entertainment] }
$$

$$
\begin{aligned}
& =\frac{2}{a} \times 100 \% \\
& =66,67 \%
\end{aligned}
$$

Aturan asosiasi yang diambil adalah aturan asosiasi yang memenuhi nilai minimum confidence telah

\begin{tabular}{|c|c|c|c|}
\hline Aturan $(A \rightarrow B)$ & \begin{tabular}{|l|} 
Sup \\
$(A \cup B)$
\end{tabular} & Sup (A) & Confidence \\
\hline Business, Children's Book $\rightarrow$ Entertainment & 2 & 2 & $100 \%$ \\
\hline Business, Entertainment $\rightarrow$ Children's Book & 2 & 3 & $66,67 \%$ \\
\hline Children's Book, Entertainment $\rightarrow$ Business & 2 & 2 & $100 \%$ \\
\hline Agriculture $\rightarrow$ Children's Book & 2 & 2 & $100 \%$ \\
\hline Children's Book $\rightarrow$ Agriculture & 2 & 3 & $66,67 \%$ \\
\hline Business $\rightarrow$ Children's Book & 2 & 3 & $66,67 \%$ \\
\hline Children's Book $\rightarrow$ Business & 2 & 3 & $66,67 \%$ \\
\hline Business $\rightarrow$ Entertainment & 3 & 3 & $100 \%$ \\
\hline Entertainment $\rightarrow$ Business & 3 & 3 & $100 \%$ \\
\hline Children's Book $\rightarrow$ Entertainment & 2 & 3 & $66,67 \%$ \\
\hline Entertainment $\rightarrow$ Children's Book & 2 & 3 & $66,67 \%$ \\
\hline
\end{tabular}
ditetapkan sebelumnya yaitu $75 \%$. Sehingga didapat aturan asosiasi sebagai berikut :

\section{Flowchart Algoritma Apriori}

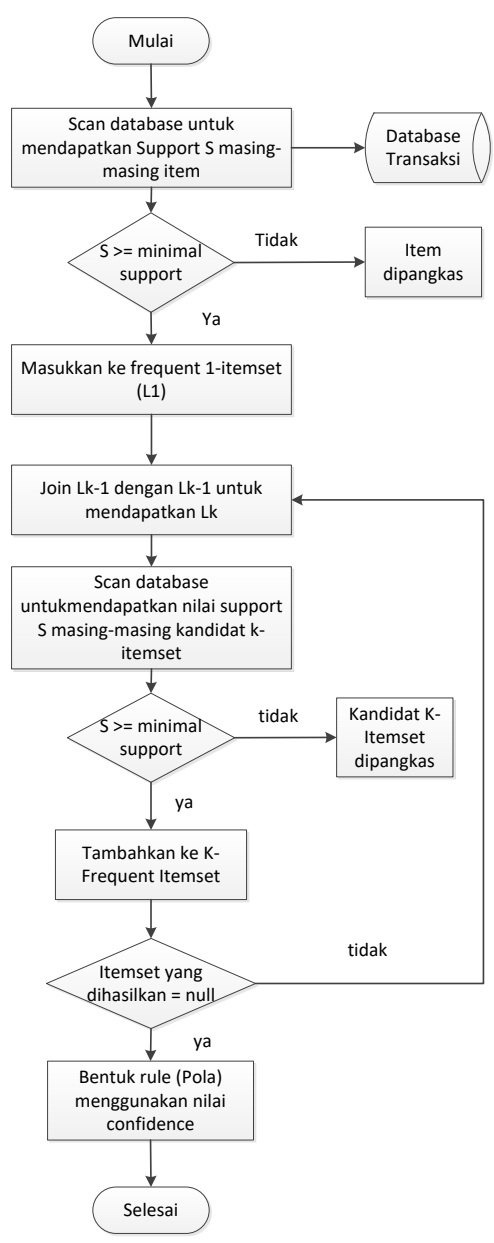

Gambar 3 Flowchart Algoritma Apriori

\subsubsection{Perancangan UML}

Pada gambar dibawah ini merupakan use case diagram usulan yang menggambarkan kegiatan - kegiatan pada aplikasi.

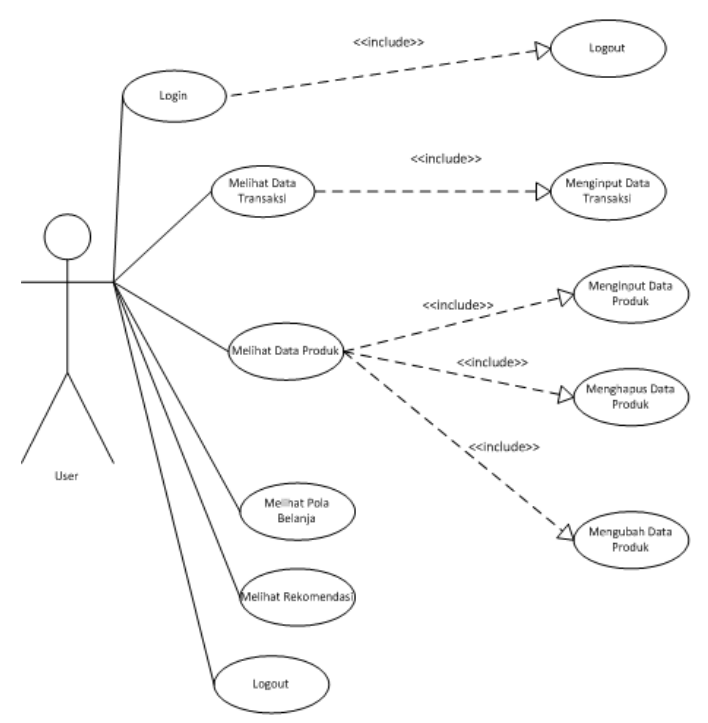

Gambar 4 Use Case diagram

Berikut adalah class diagram dari aplikasi yang akan dibangun :

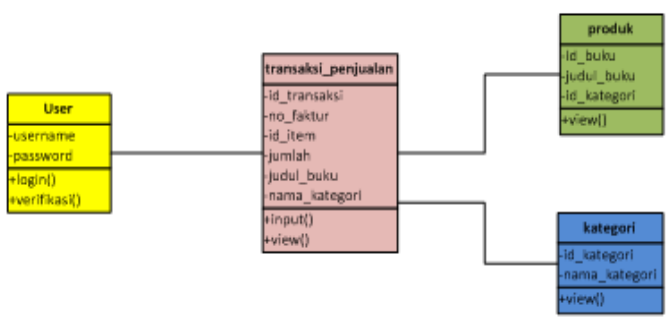

\section{Gambar 5 Class Diagram}

\subsubsection{Perancangan Database}

Dalam penyimpanan data, penulis menggunakan MySQL database. Struktur database pada Aplikasi analisa pola belanja

\begin{tabular}{|c|c|c|c|}
\hline \multirow[t]{4}{*}{ Database } & Tabel & Coloumn & Type \\
\hline & \multirow[t]{3}{*}{ produk } & id_buku & int(10) \\
\hline & & judul_buku & varchar(50) \\
\hline & & kategon & varchar(50) \\
\hline & \multirow[t]{2}{*}{ kategori } & id_kategori & $\operatorname{int}(10)$ \\
\hline & & nama_kategori & varchar(25) \\
\hline & \multirow[t]{6}{*}{ transaksi_penjualan } & id_trans & $\operatorname{int}(25)$ \\
\hline & & no_faktur & $\operatorname{int}(25)$ \\
\hline & & id_item & $\operatorname{int}(25)$ \\
\hline & & jumlah & $\operatorname{int}(10)$ \\
\hline & & judul_buku & varchar(50) \\
\hline & & nama_kategori & varchar(25) \\
\hline & \multirow[t]{3}{*}{ user } & id & $\operatorname{int}(10)$ \\
\hline & & usemame & $\operatorname{varchar}(25)$ \\
\hline & & password & varchar(25) \\
\hline
\end{tabular}
terdiri dari :

Tabel 3 Perancangan Database

3.5. Implementasi Fitur (Build by Feature) 
Pada tahap ini, penulis melakukan pembuatan fitur-fiur yang telah dirancang sebelumnya yaitu berdasarkan UML, flowchart dan pseudocode yang telah dibahas pada tahap perancangan fitur, yang selanjutnya akan diterjemahkan ke dalam sebuah kode (coding).

A. Hasil dan Analisa

Berikut hasil analisa pola belanja konsumen yang dihasilkan oleh aplikasi analisa pola belanja :

Tabel 4 Hasil Analisa Pola

\begin{tabular}{|l|l|l|}
\hline Kombinasi (A $\rightarrow$ B) & $\begin{array}{l}\text { Nilai } \\
\text { support }\end{array}$ & $\begin{array}{l}\text { Nilai } \\
\text { Confidence }\end{array}$ \\
\hline Fiction Literature $\rightarrow$ Children's Book & $5,13 \%$ & $32,47 \%$ \\
\hline $\begin{array}{l}\text { Children's Book } \rightarrow \text { Religion } \\
\text { Spirituality }\end{array}$ & $8,24 \%$ & $20,70 \%$ \\
\hline $\begin{array}{l}\text { Children's Book } \rightarrow \text { Schoolbooks } \\
\text { Indonesia Curriulum }\end{array}$ & $11,22 \%$ & $28,20 \%$ \\
\hline $\begin{array}{l}\text { Religion \& Spirituality } \rightarrow \text { Children's } \\
\text { Books }\end{array}$ & $8,24 \%$ & $29,31 \%$ \\
\hline $\begin{array}{l}\text { Religion \& Spirituality } \rightarrow \text { Schoolbooks } \\
\text { Indonesia Curriculum }\end{array}$ & $7,53 \%$ & $26,77 \%$ \\
\hline $\begin{array}{l}\text { Schoolbooks Indonesia Curriculum } \rightarrow \\
\text { Children's Books }\end{array}$ & $11,22 \%$ & $30,66 \%$ \\
\hline $\begin{array}{l}\text { Scholbooks Indonesia Curriculum } \rightarrow \\
\text { Religion \& Spirituality }\end{array}$ & $7,53 \%$ & $20,56 \%$ \\
\hline
\end{tabular}

Tabel diatas adalah hasil dari proses analisis pola yang telah dijalankan dengan memberikan nilai minimum support $=5 \%$ dan nilai minimum confidence $=15 \%$ dari hasil analisis pola dihasilkan sebanyak 7 pola dengan stong rule (pola yang memiliki nilai support dan nilai confidence relative tinggi) yang didapatkan adalah Schoolbooks Indonesia Curriculum $\rightarrow$ Children's Books atau bisa dibaca jika konsumen membeli buku Schoolbooks Indonesia Curriculum maka konsumen membeli Children's Books dengan nilai support $11,22 \%$ dan nilai confidence $=30,66 \%$.

Hasil analisis pola diatas menunjukkan bahwa nilai support yang semakin besar dari sebuah kombinasi buku akan memberikan rekomendasi buku berdasarkan buku yang sering dibeli dalam data transaksi, sebaliknya semakin kecil nilai support suatu kombinasi buku artinya rekomendasi diberikan berdasarkan buku yang jarang dibeli oleh konsumen. Sedangkan untuk nilai confidence yang semakin besar maka semakin besar kemungkinan buku yang direkomendasikan ketika konsumen memilih buku tertentu.

Dengan menggunakan pola yang dihasilkan dapat dijadikan rekomendasi oleh pihak Gramedia untuk menentukan tata letak buku dan juga bisa dijadikan sebagai rekomendasi pada pencarian di Gramedia Online. Sebagai contoh, untuk tata letak buku pola Schoolbooks Indonesia Curriculum $\rightarrow$ Children's Books apabila dijadikan untuk rekomendasi pengaturan tata letak buku, maka posisi Schoolbook Indonesia Curriculum dapat diposisikan berdekatan dengan buku Children's Book. Sedangkan pada Gramedia Online pola yang dihasilkan dapat dijadikan rekomendasi untuk pencarian sebuah buku. Sebagai contoh, pada saat user meng-input keyword Schoolbook Indonesia Curriculum maka akan besar kemungkinan muncul rekomendasi buku untuk Children's Book atau buku-buku lain yang berkombinasi dengan buku Schoolbook Indonesia Curriculum dalam data transaksi.

B. Pengujian

\section{Uji Kesesuaian Algoritma}

Uji kesesuaian algoritma apriori dilakukan untuk membuktikan kebenaran terhadap perhitungan yang dilakukan oleh algoritma apriori yang mana proses pengujian dilakukan dengan membandingkan hasil perhitungan data yang dilakukan oleh algoritma dengan hasil perhitungan yang dilakukan secara manual. Pengujian dilakukan terhadap hasil pencarian pola pada aplikasi yang menggunakan 10000 rows data, nilai minimum support $=5 \%$ dan nilai minimum confidence $=15 \%$ dan menghasilkan 7 pola. Berikut pola yang dihasilkan oleh aplikasi analisa pola belanja :
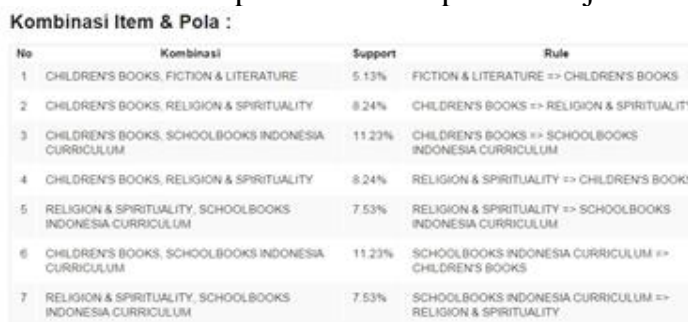

Gambar 6 Hasil Analisis Pola

Berikut adalah hasil perhitungan manual terhadap pola dan kombinasi yang dihasilkan diatas dari 3919 data transaksi :

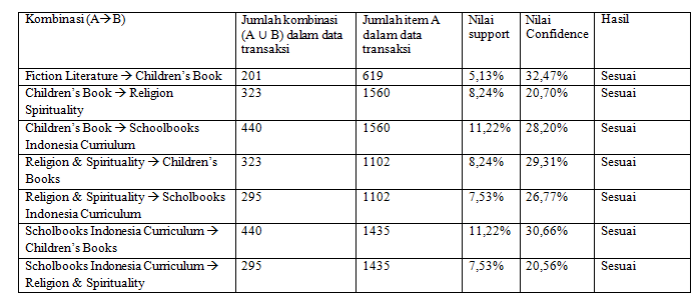

\section{Pengujian Waktu}

Berikut adalah hasil pengujian waktu yang dilakukan untuk melihat waktu yang dibutuhkan untuk memproses algoritma berdasarkan jumlah data. 


\begin{tabular}{|l|l|l|}
\hline Jumlah Data & Nilai support \& confidence & Waktu Eksekusi \\
\hline \multirow{3}{*}{100 rows } & Support $=2 \%$ confidence $=5 \%$ & 0,06 detik \\
\cline { 2 - 3 } & Support $=5 \%$ confidence $=15 \%$ & 0,01 detik \\
\hline \multirow{3}{*}{500 rows } & Support $=2 \%$ confidence $=5 \%$ & 0,17 detik \\
\cline { 2 - 3 } & Support $=5 \%$ confidence $=15 \%$ & 0,03 detik \\
\hline \multirow{2}{*}{1000 rows } & Support $=2 \%$ confidence $=5 \%$ & 0,26 detik \\
\cline { 2 - 3 } & Support $=5 \%$ confidence $=15 \%$ & 0,06 detik \\
\cline { 2 - 3 } & Support $=2 \%$ confidence $=5 \%$ & 0,28 detik \\
\hline \multirow{2}{*}{10000 rows } & Support $=2 \%$ confidence $=5 \%$ & 1,28 detik \\
\cline { 2 - 3 } & Support $=5 \%$ confidence $=15 \%$ & 0,97 detik \\
\hline
\end{tabular}

Berdasarkan pengujian waktu diatas dapat disimpulkan bahwa semakin banyak data yang diproses algoritma apriori, maka akan membutuhkan waktu eksekusi yang lebih lama, dan sebaliknya. Jika nilai minimum support dan nilai minimum conflidence yang diatur semakin besar maka akan mempercepat waktu eksekusi, jika semakin kecil nilai yang diatur maka waktu eksekusi yang dibutuhkan akan lebih lama.

\section{KESIMPULAN DAN SARAN}

\subsection{Kesimpulan}

Berdasarkan pembahasan penelitian yang penulis lakukan, dapat disimpulkan bahwa :

1. Penerapan Algoritma Apriori dalam penelitian ini adalah untuk mencari kombinasi item terbanyak berdasarkan data transaksi dan kemudian membentuk pola asosiasi dari kombinasi item tersebut.

2. Pola asosiasi yang terbentuk dengan nilai minimum support 5\% dan nilai minimum confidence 15\% menghasilkan 7 aturan asosiasi. Dan strong rules yang didapatkan adalah schoolbooks indonesia curriculum $\rightarrow$ children's book dengan nilai support $11,23 \%$ dan nilai confidence $30,66 \%$.

3. Analisis pola yang dihasilkan aplikasi ini dapat digunakan oleh pihak Gramedia untuk pengaturan tata letak buku, rekomendasi pencarian buku pada Gramedia Online dan lain-lainya, yang mana setiap bulannya pola yang dihasilkan bisa berbeda-beda sesuai data transaksi yang dianalisis.

4. Semakin besar jumlah data yang di proses maka semakin lama waktu yang dibutuhkan. Semakin besar nilai support dan nilai confidence yang diatur maka akan semakin singkat waktu pemprosesan algoritma.

\subsection{Saran}

Untuk pengembangan lebih lanjut, terdapat beberapa hal yang penulis sarankan agar aplikasi analisa pola belanja menjadi lebih baik yaitu :
1. Diharapkan pengembangan selanjutnya menggunakan algoritma lain untuk mendapatkan hasil yang lebih optimal, tidak hanya mempertimbangkan waktu, tetapi juga mempertimbangkan akurasi pola yang dihasilkan dan dapat memproses data dalam jumlah besar.

2. Melakukan perbandingan terhadap hasil metode data mining yang satu dengan yang lainnya untuk dapat sehingga mendapatkan perbandingan mana algoritma yang lebih baik untuk diterapkan

3. Penambahan fitur cetak untuk mencetak hasil analisis pola dan hasil pencarian rekomendasi, serta penambahan fitur yang dapat mengatasi beberapa permasalahan lain yang terjadi di Gramedia.

\section{DAFTAR PUSTAKA}

Adewole, K.S, dkk. Frequent Pattern and Association Rule Mining from Inventory Database Using Apriori Algorithm. Computer Science. Nigeria : University of Ilorin

Agrawal, Rakesh dan Ramakrishnan Srikant. 1994. Fast Algorithm for Mining Association Rules. California : IBM Almaden Research Center

Buulolo, Efori. 2013. Implementasi Algoritma Apriori Pada Sistem Persediaan Obat (Studi Kasus : Apotik Rumah Sakit Estomihi Medan).

Erwin. 2009. Analisis Market Basket Dengan Algoritma Apriori dan FP-Growth. 2009. Teknik Informatika. Sumatera Selatan : Universitas Sriwijaya.

Goyal, Sadhna. 2008. Major Seminar on Feature Driven Development : Agile Techniques for Project Management and Software Engineering. Technical University Munich.

Han, Jianwei \& Micheline Kamber. 2006. Data Mining Concept and Techniques. United States of America : Elsevier Inc.

Hermawati, Fajar Astuti. 2013. Data Mining. Yogyakarta : Andi.

http://www.kompasgramedia.com/business/booksto res/gramedia

Kusrini dan Luthfi, E.T. 2009. Algoritma Data Mining. Yogyakarta: Andi

Lestari, Tri. 2009. Analisis Keranjang Belanja pada Data Transaksi Penjualan (Studi Kasus Toserba Yogyakart). Manajemen. Institut Pertanian Bogor.

Luthfi, Ema Taufiq. 2009. Penerapan Data Mining Algoritma Asosiasi untuk Meningkatkan 